\title{
THE POTENTIAL OF MICROFINANCED HOUSING AFTER PAKISTAN DISASTERS
}

\author{
F. TARIQ \\ Beaconhouse National University, Pakistan.
}

\begin{abstract}
Traditional modes of providing physical infrastructure, especially housing after disaster on unimproved settlements for the urban poor is unlikely to meet the increased demand. Conventional high-level services do not prove to be affordable or suitable for the poor. In Pakistan, owning a decent house seems an unachievable dream for the poor especially after a series of natural disasters. An innovative strategy involving a participatory approach is an urgent need of the times. This requires planning for the provision of housing with a view to subsequent upgrading, which is to be managed by householders and communities. The housing solution proposed in this paper revolves around global movement of microfinance that is expanding day by day to empower low-income communities through small-scale loans. Besides assisting income-generating activities, microfinance for house building has also attained a prominent position in many countries. This study will discuss the financial solutions related to incremental housing based on empirical knowledge gained from case studies all over the world. Implications for households and institutions are addressed and reference is made to the experiences of the lowincome households and microfinance practices in Pakistan.
\end{abstract}

Keywords: Incremental Housing, Microfinance, Participation.

\section{DISASTERS IN PAKISTAN}

"Developing countries suffer the greatest costs when a disaster hits - more than 95 percent of all deaths caused by disasters occur in developing countries and underdeveloped countries, and losses due to natural disasters are 20 times greater in developing countries than in industrialized countries" Dilley [1].

In the last decade, Pakistan has faced a series of terrible disasters. These tragic events apart from creating substantial physical damage and loss of life, has led the country into severe economic depression. Disasters include the 2005 Kashmir earthquake, which centered in Pakistan-administered Kashmir and Islamabad. This event registered a moment magnitude of 7.6. The Margalla Towers, an apartment complex in Islamabad collapsed and killed most of the residents. As of $8^{\text {th }}$ November, the official death toll reached 75,000 [2]. The overall number of destroyed shelters reached 600,000 houses. The severity of the damage caused by the earthquake is attributed to the severe upthrust force, coupled with poor construction.

The 2010 Pakistan floods began in late July, resulting from heavy monsoon rains in the Khyber Pakhtunkhwa, Sindh, Punjab and Baluchistan regions of Pakistan. Approximately one-fifth of Pakistan's total land area was underwater [3]. According to government data, the floods directly affected about 20 million people, "mostly by destruction of property, livelihood and infrastructure, with a death toll close to 2,000. Damage to structures was estimated to exceed US $\$ 4$ billion and the number of destructroyed shelters is one million" Kaleem and Ahmed [4].

A report by Islamic Relief, a non-profit relief and development organization, indicates: "that the international response has been insufficient to help Pakistan recover from 2010 devastating floods - the country's worst natural disaster on record. It forced 11 million people from their homes" [5]. According to the World Health Organization, millions more have since become ill from waterborne diseases, with the total death toll unknown. 


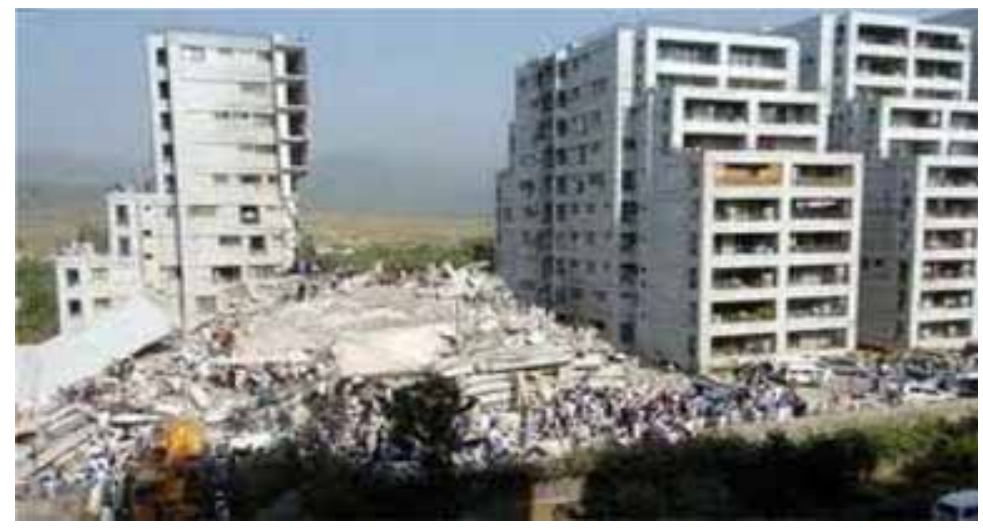

Figure 1: Margalla towers after October 2005 earth quake.
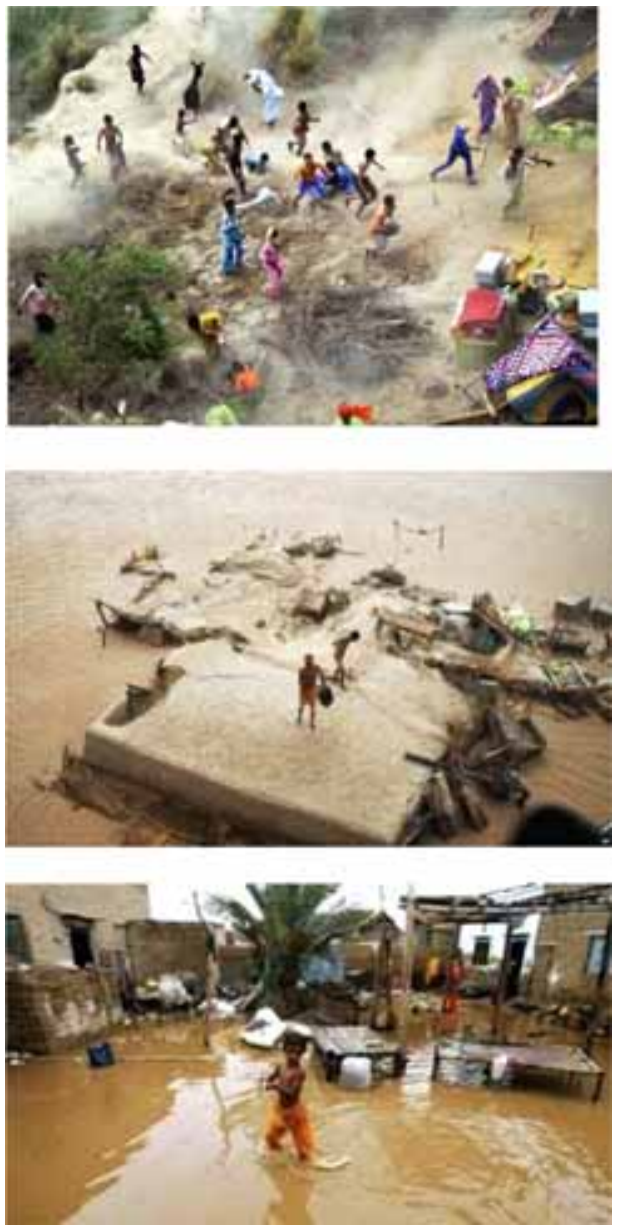

Figure 2: Some scenes from July-August 2010 Pakistan floods. 


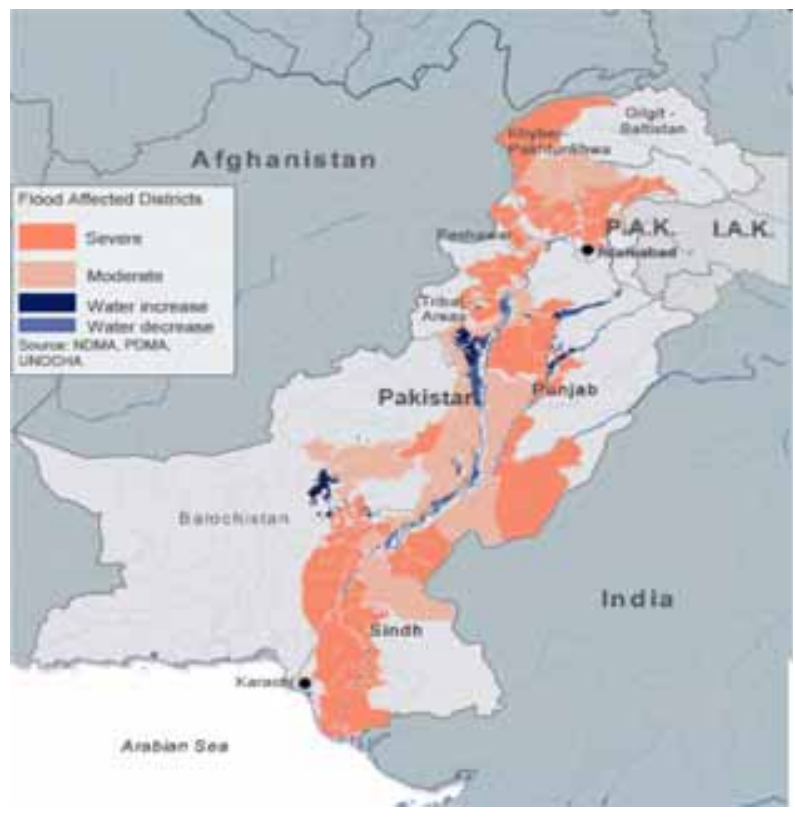

Figure 3: Map showing the spread of 2010 flood with intensity.

\section{POST DISASTER EFFORTS}

Floods and earthquakes continue to wreck havoc across Pakistan, destroying entire villages and huge areas of farmland. An estimated 20 million people have been affected in the last decade. Many are still in dire need of food, drinking water, shelter and other relief supplies. Pakistan is still waiting for the United Nations, the World Bank and the U.S. government to deliver promised billions of dollars in aid. As reported on National Public Radio (NPR), August 2010, "after the Pakistani quake only about 150 million dollars was given, even though there were 80,000 deaths and four million homeless. Compare these sums with Haiti, where 1.4 billion was given in relation to 9.7 million and 20 million people are affected. So this is already double the entire population of Haiti" [6]. A number of post disaster construction activities have been initiated, including 10,000 housing units constructed in flood-affected areas by Pakistan's largest private sector land developer. Miscellaneous efforts have also been initiated by the government of Punjab, the National Disaster Management Authority of Pakistan, armed forces, local NGOs and UN HABITAT-Pakistan.

According to Oliver [7], the activities and outputs in rehabilitation and reconstruction after a disaster were different in their scope and scale. The provision and installation of tents, temporary shelter and food distribution occur during the rehabilitation period and the provision of permanent housing, industry structures, infrastructure and education occur during the reconstruction period. In the words of Johnson [8]; "temporary housing is a crucial but controversial part of disaster recovery; disaster-affected families who have lost their homes need a private and secure place to restart their daily activities as soon as possible after the disaster, yet temporary housing programmes tend to be overly expensive, too late, and responsible for undesirable impacts on the urban environment."

Improved strategies for post-disaster reconstruction are more than ever of prime importance for developing countries. Yet "existing approaches to housing reconstruction are not 
effective in re-establishing the lowest-income communities after natural disasters, nor in contributing to their long-term development" Davidson, Johnson and Lizarralde [9]. Reconstruction strategies, according to Dilley [10], generally fall into one of two extremes i.e. "almost total reliance on aided self-help reconstruction or reliance on the import of dwellings from the developed donor countries".

Universal standard prototype shelters are not feasible because they are high priced. As these shelters are built internationally, in most cases they are unable to respond to with variations in local climate, cultural values and specifically local housing forms.

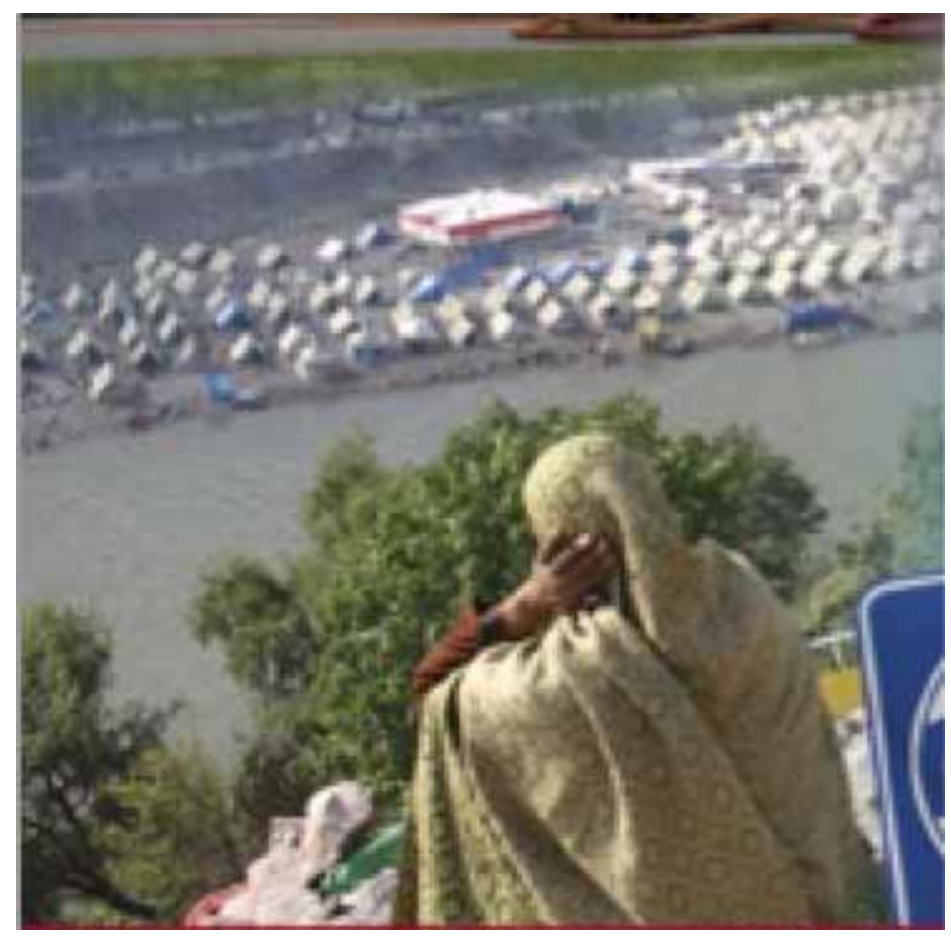

Figure 4: Recent prototype tents.

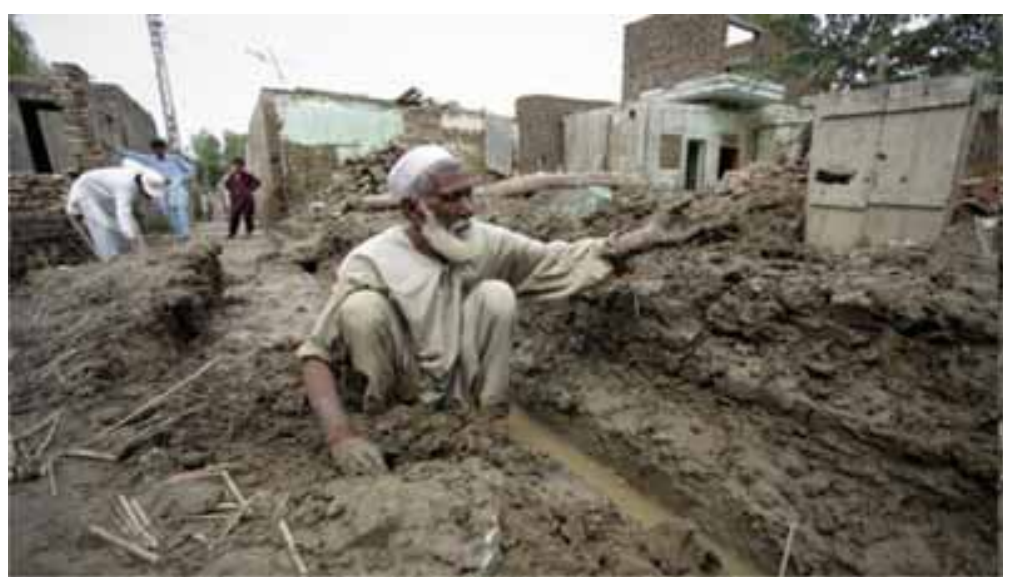

Figure 5: A survivor rebuilding house in Nowshera, Pakistan. 
Dorosh, Malik and Krausova [11] discuss some of the specific challenges that arise after floods in Pakistan. They argue that there has traditionally been a lack of coordination among institutions at the federal and provincial government levels in Pakistan and so the damage assessment plan was not implemented effectively. Also there is a growing concern about channelization of relief funds and rehabilitation. Political inconsistency is considered to be a serious constraint to the effectiveness of any relief and rehabilitation measure. Especially in the northern areas of Khyber and in the province of Pakhtunkhwa, capacity and delivery issues arose after the floods. These areas were unable to protect the population with the basic necessities like shelter and food. The lack of transportation facilities, in-sufficient supplies of tents and lack of information about disaster mitigation continue to be major constraints in disaster areas of Pakistan.

\section{HOUSING SHORTAGE}

According to Dilley [12], post-disaster housing can be classified in to four groups:

1. Non-affected housing.

2. Housing affected by the disaster but where repair is more effective than reconstruction.

3. Housing affected by the disaster that cannot be occupied because it represents unsafe conditions for the residents.

4. Pre-disaster deficit housing and homelessness.

Pakistan already had a huge housing deficit prior to the recent tragedies. In early 2010, Central Bank of Pakistan statistics revealed a total shortage of 8.8 million houses and proposed that 700,000 houses/year must be provided to cope with the increasing demand. Vulnerable housing conditions make the situation worse. In most of the villages of Pakistan, and along rivers, houses are still constructed with mud. Earthquakes and floods strike more in areas with more vulnerability.

To cover this backlog, government agencies in Pakistan have experimented with a wide range of low-income housing programs including sites and services, low-cost core units and slum upgrades. However, government-produced housing covers a negligible part of need, even though many agencies are involved in the Pakistani housing sector as listed below [13]:

1. Ministry of Housing \& Works

2. National Housing Authority

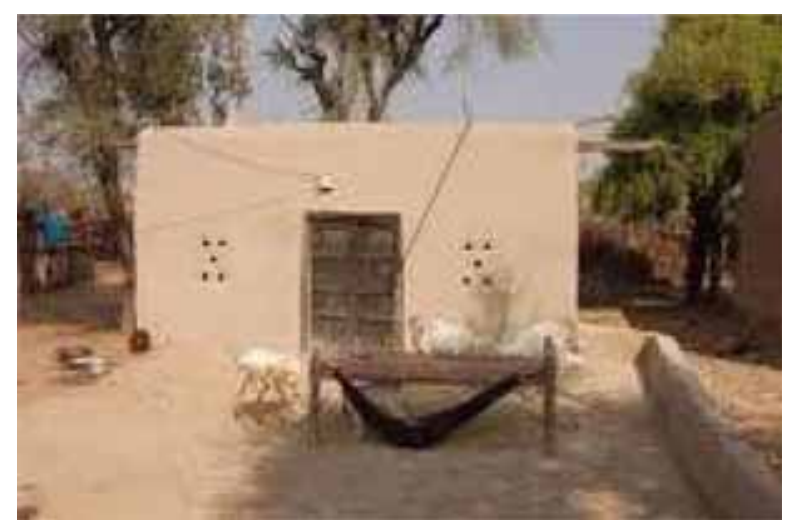

Figure 6: Typical mud house in a village of Pakistan. 


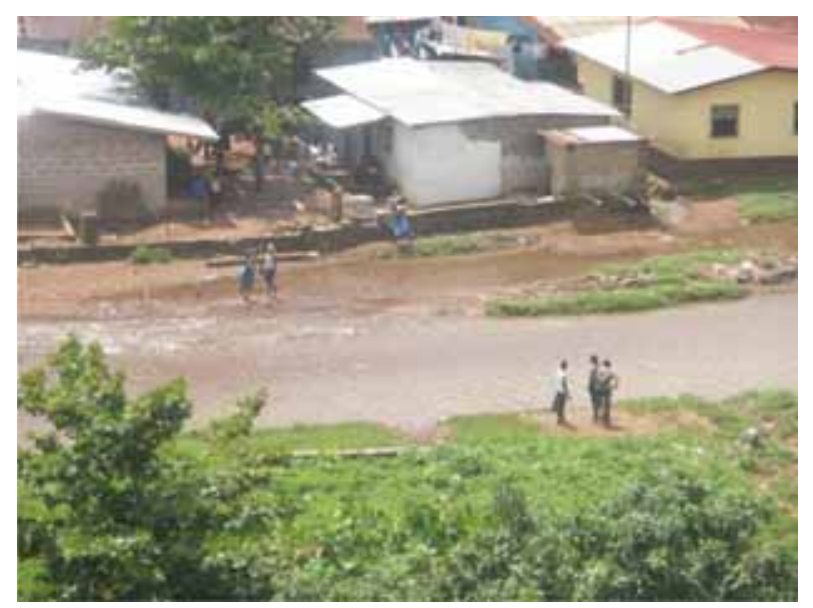

Figure 7: Houses along the river bank.

\section{Planning Commission of Pakistan}

4. Federal Board of Revenue

5. Punjab Department of Housing, Urban Development \& Public Health Engineering

6. Punjab Housing \& Town Planning Agency (PHATA)

7. Sind Housing \& Works Department

8. Baluchistan Communication, Works, Physical Planning \& Housing

9. $(\mathrm{C} \& \mathrm{~W})$ Department

10. NWFP Department of Housing

11. Area Development Authorities

12. Sind Katchi Abadies Authority (SKAA)

13. Punjab Directorate General of Katchi Abadies \& Urban Improvement

14. Sind People's Housing Cell

15. Punjab Urban Unit

16. Punjab Municipal Development Fund Co.

17. City District Governments

18. Tehsil Municipal Administration (TMAs)

19. Water \& Sanitation Agency (WASA)

20. Environment Protection Agency

21. House Building Finance Corporation (HBFC)

22. Khushhali Bank

23. Network Microfinance Bank Limited (NMBL)

The housing and financial solutions provided by these agencies cannot gain popularity because either they are inconveniently far from the main city or have high interest rates for financing. This happens to most government developed low-income housing projects. The public sector's failure to anticipate and respond to housing demand of low-income people continues to result in the creation of slums or irregular settlements known as katchi abadis all over the country [14]. On the other hand, the formal housing finance institutions require collateral in the form of land or the house itself so that the loans can be recovered in the event of default. As poor people do not have credit records, regular incomes or land/house collateral, 
they are not eligible to apply for formal financing offered by these institutions. According to Akhtar [15] more than $80 \%$ of the total population of Pakistan cannot afford the financing terms provided by HBFC and other housing finance institutions. "A Rs. 300,000 mortgage loan at $20 \%$ for 12 years requires a monthly payment of about Rs. 5,500, a payment that only a small percentage of families can afford to make."

\section{HOUSING SOLUTION}

In the words of Lizarralde [16] "treat post-disaster reconstruction as a continuum from immediate relief to long-term rebuilding practice." The improvements in post-disaster strategies, if integrated with a reasoned approach, can help in building sustainable housing solutions. "It has been widely accepted by policy makers and commentators, funding bodies and NGOs that the vital success in low-cost housing projects in developing countries lies in community participation" Davidson, Johnson and Lizarralde [17].

As the interplay of external and internal factors created unfavorable conditions for poor families of Pakistan to construct their houses, the approach discussed in this paper broadens the notion of house construction, giving greater freedom to people to build their own houses. This paper couples local building attitudes towards incremental housing with imported financial solutions. Data has been gathered from international housing finance practices and local families who have conducted incremental construction with and without housing microfinance after disasters. There are many studies which reveal that poor people build and improve houses incrementally as needs arise. "Incrementalism is a method of working, by adding to a project, many small (often unplanned), incremental changes instead of a few (extensively planned) large jumps" [13]. "A useful approach for housing in this context offers a wider range of low-cost solutions rather than just complete new units" NHP [18]. "For individuals or households with limited incomes, the only possibility of home ownership (even in an illegal settlement) is through shelter investment made in several stages, all are made at separate times" Ferguson and Navarrete [19]. As "incremental building demand incremental financing" Abrams [20]. According to Smets [21], a microloan with maturity period of 5 years or less can enable flexibility, as labor and materials are added incrementally for construction or improvement over a period of years. Incremental housing facilitates access to housing opportunities through a phased process and housing microfinance can facilitate this incremental construction. The global report on human settlements-2005 also emphasized the fact that "finance is the most important dimension of securing sustainable solutions that can fill the gap between the two extreme outcomes of current systems and processes: affordable shelter that is inadequate and, adequate shelter that is unaffordable" Habitat [22].

The housing solution proposed in this paper has been conducted through three phases: data was gathered from international housing microfinance practices and from people doing incremental housing with and without housing microfinance. From this, the processes were appraised; and at a final stage, housing solutions are proposed to be achieved through facilitation of housing microfinance. All this is supposed to influence and contribute to policy making. The above-stated themes and their inter-relations are shown diagrammatically as follows.

\subsection{International housing microfinance practices}

It is evident from the literature that housing microfinance makes up a noteworthy bridging resource that allows for the necessary financial support to poor families in order to construct 


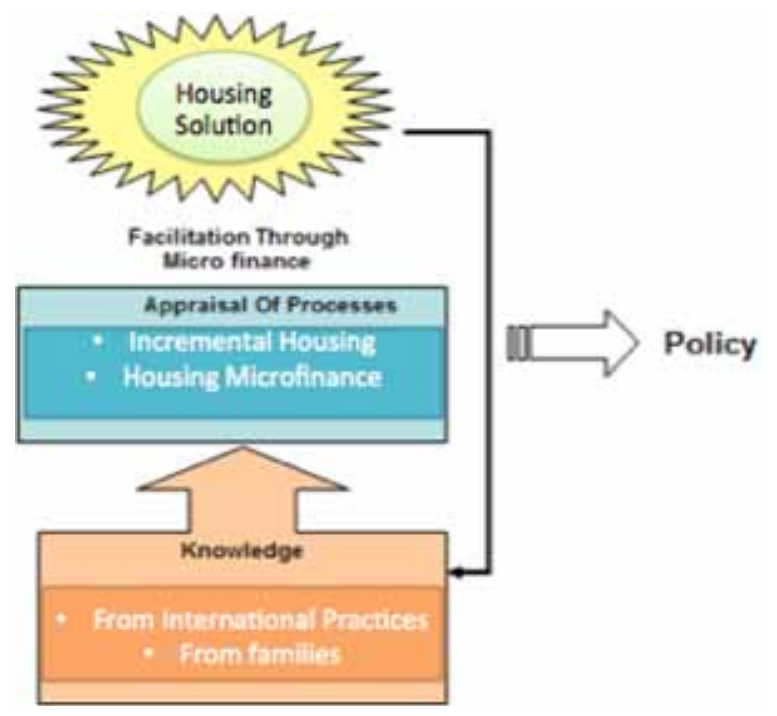

Figure 8: Housing solution.

their houses incrementally. Following are the examples of the few organizations whose housing microfinance practices have had an impact on national and international level:

In El Salvador by NGO Argoz and Financiera Calpia, in La Paz by Mutual La Primera [23], in Thailand by Community Organization Development Institute [24], in Malawi by Malawi Federation, in Chile by Progressive House Programme (PHP) and Ministerio de Vivienda y Urbanismo-group (MINVU) [25], in Namibia by Shack Dwellers Federation and Namibia Housing Action Group [26] and in Bogota-Colombia by Guacamays [27].

\subsection{Housing microfinance in Pakistan}

There are a few organizations in Pakistan like Akhuwat, Kashf foundation and Khushhali bank that are disbursing microloans. Most of these started with an enterprise loan. The NGOs that are working specifically for housing microfinance include the housing loan program of the Catholic Social Services in Karachi, which operated from 1981 to 1992 and disbursed 833 housing loans. Akhuwat has dispersed 220 housing loans in Lahore since 2005. The average loan amount is $\$ 470-600$ with a maturity period of two years. The Aga Khan Agency for Microfinance operates only in Gilgit-Baltistan and Chitral.

To gather local data about housing microfinance practice in Pakistan, the families doing incremental house construction with or without microfinance were interviewed. These families were selected from the portfolio of NGO-Akhuwat. As compared to the international housing microfinance practices, the one in Pakistan has indeed some cultural and religious differences. The NGO-Akhuwat has practiced some important strategies for disbursing housing loans. They market the loan product through Mosques and disburse it also in Mosques. Each branch NGO is located within or just outside the mosque's premises. Introduction to the program is also given after prayers when people have congregated there. Hence they assume that the NGO is sincere enough in a sacred place. It also provides interest-free loans, as interest is forbidden in Islam; hence many people are attracted towards it. Akhuwat, which means brotherhood, has been funded by wealthy Muslims through Zakat, which is also a religious 


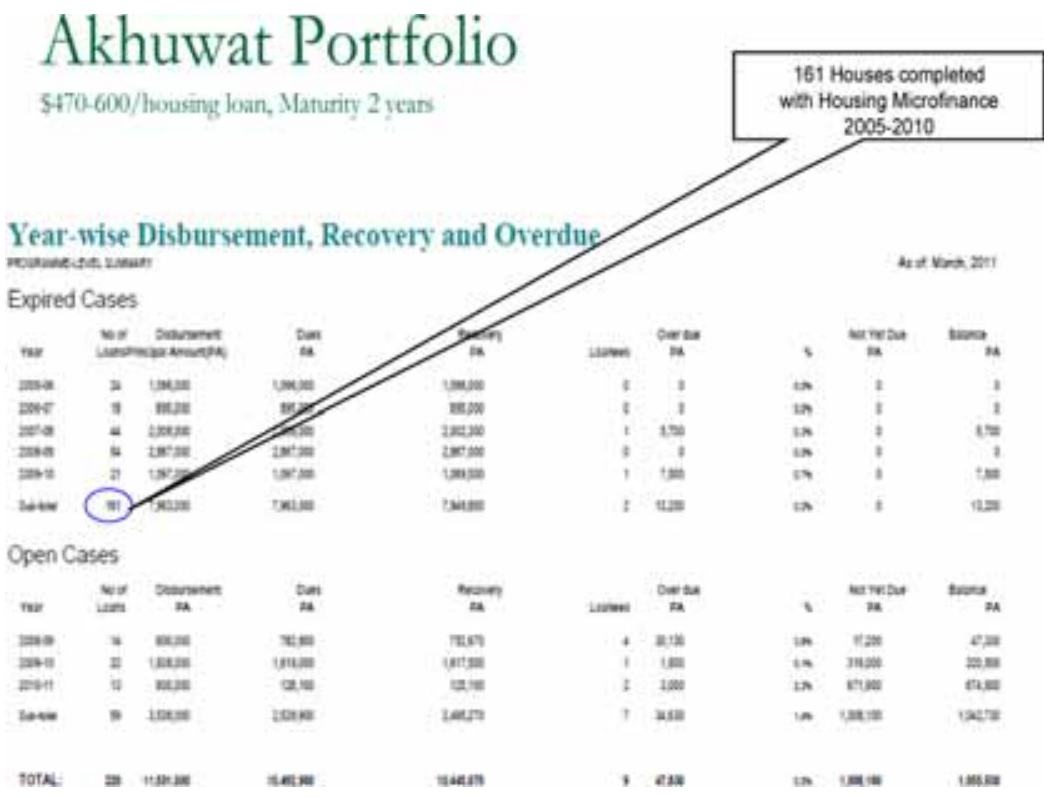

Figure 9: Akhuwat housing loan portfolio [30].

obligation to pay yearly for the benefit of the poor in the Muslim community. Akhuwat involved families in signing a loan agreement, which shows involvement of women in the process [28]. As stated by Datta and Jones [29], "extended Muslim families practicing purda requires a separate space for the female members of the family. Moreover, especially female members of the household require adequate housing because they often combine their roles of regeneration, income generation and management in and around the house. Innovative housing finance lenders can deal exclusively with finance or combine it with a welfare or social development focus".

\subsection{Research findings}

The in-depth interviews were used to collect data regarding experiences in incremental housing with and without housing microfinance. Most of the families recommend government to take steps similar to NGO-Akhuwat for reconstruction after disasters. People appreciated the practice because the loan money is interest free and has a maturity period of only 2 years. In most cases the loan money has been seen as an opportunity to upgrade the houses to enhance the flood resistance.

The lengthy disbursement procedures and small loan amount (in most cases only US \$650) were only the few complaints.

\subsection{Recommendations}

The efforts of the NGO are worth mentioning but the scale of housing shortage is so huge that it needs a comprehensive policy guideline. In order to make recommendations that meet the affordable housing demand throughout Pakistan especially after disasters, there is a need to broaden the platform of housing agents involved. Out of informal and formal 


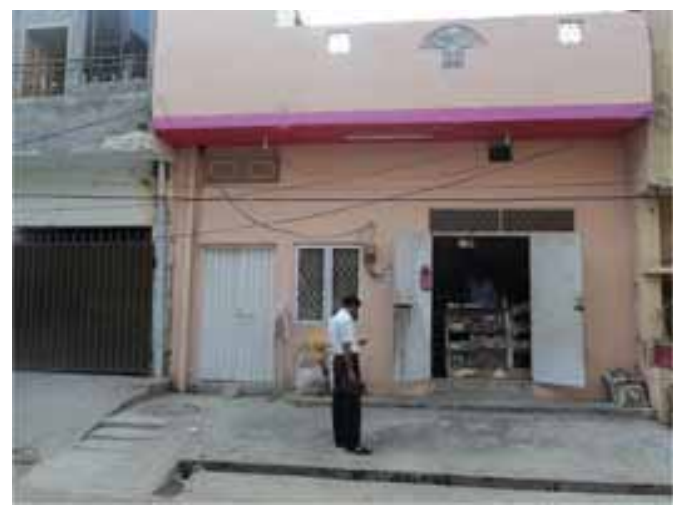

Figure 10: Shop in a house opened by female family member with microfinance.
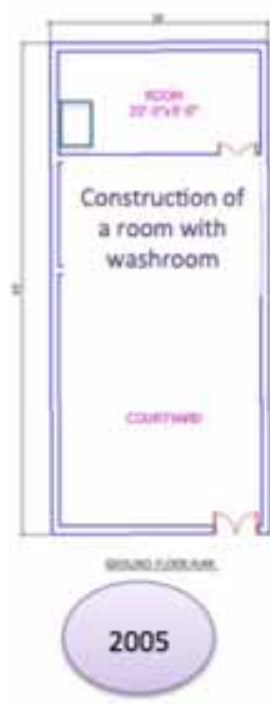
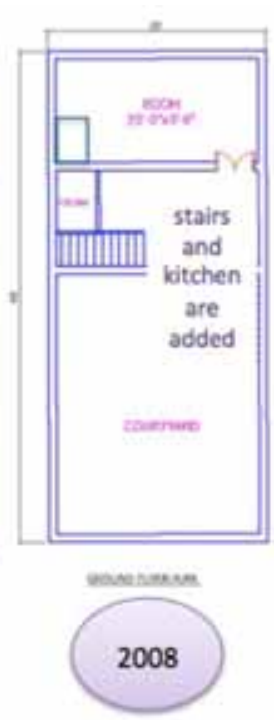
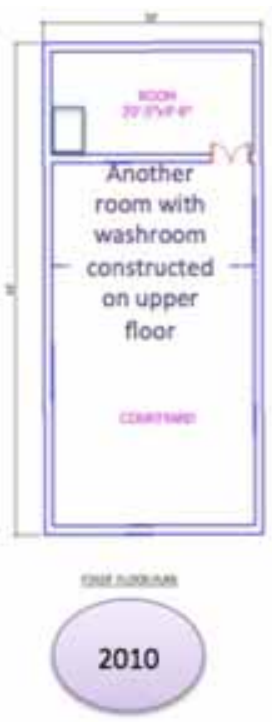

Figure 11: Incremental construction of a house in Lahore with housing microfinance.

housing providers, no organization contains the range of products and services necessary to support incremental housing and finance comprehensively. Hence, assembling alliances among governmental agencies, microfinance institutions (NGOs), building material retailers and manufacturers, households, researchers, architects and civil engineers is an imperative need of the hour shown in the following figure.

The role of each is elaborated below:

\subsubsection{Role of government}

Joining Micro Finance Institutions (MFI), government policies and a household's traditions together, had also worked well for assisting low-income households. Such programs have a long history in countries like Latin America [31]. A Mexican MFI, Financiera Independencia and the federal government second-tier housing Bank - SHF, have succeeded in joining 


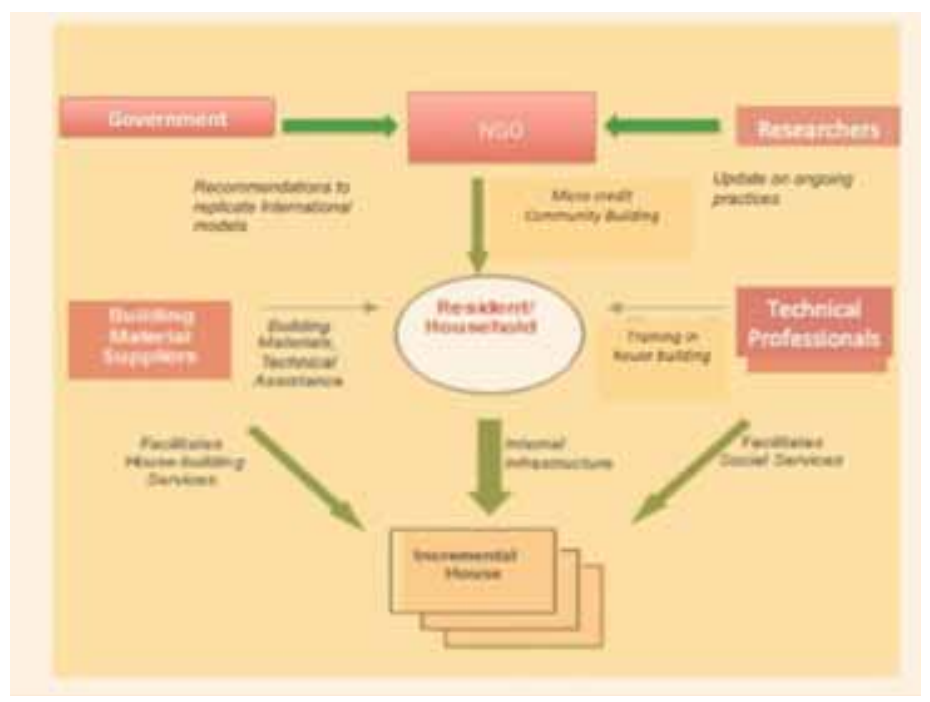

Figure 12: Proposed actors and their linkages in the proposed housing solution.

together and work for incremental housing. Their network has now grown into 128 branches. The institution offers a credit line for home improvement called Credi Construye. These loans were used for home improvement and all are extended in the form of a voucher that can be exchanged for construction materials [32]. In this solution, the government acts as a facilitator of the necessary funds in order to disburse housing micro-loans. In addition, it will hire NGO to act as an intermediary between people and government.

\subsubsection{Role of researchers}

Researchers review reports and other secondary data relevant to low-income housing and housing finance and prepare a matrix for housing microfinance. Apart from production of proposal on housing microfinance project, the researcher also monitors and evaluates the project and suggests the improvements.

\subsubsection{Role of NGOs}

Before disbursing housing loans, other activities such as a survey of the houses concerned, training in technical skills and organizing community groups need to be carried out. Special attention should also to be paid to the costs of materials; all this is organized and done by the NGOs [33]. Various studies have suggested that the use of housing microfinance NGOs as intermediaries for housing, particularly in developing countries, is really fruitful. This option has many attractions. It builds on the comparative advantage of NGOs, i.e. their ability to keep in close relationship and work with low-income households. In comparison, estate developers, large building materials manufacturers and commercial banks face considerable difficulties in working directly with low-income communities. In big developing economies such as Mexico, Brazil, India and Indonesia, some microfinance institutions may become specialized niche lenders for large distribution networks of suppliers of inputs to the progressive housing process. In this case the NGO will act as a mediator, will identify key individuals in the area and make saving groups. It will also provide technical assistance to the groups by hiring civil engineers and architects. 
4.4.4 Role of technical professionals

Incremental construction, whether it is the addition of a room or improvement of an existing structure, often involves destruction. There is a lot of waste of building materials, labor and all other resources. "However should shelter be constructed in the most efficient way"? Smets [34]. Yes and with some design guidance, the incremental construction of housing could be done with much less waste. The lack of involvement of technical advice on incremental construction results in low quality and therefore creates great environmental and land use problems. Mohni Malhotra in her article "Financing her home, one wall at a time" had given example of Grameen housing loan products which required borrowers to meet minimum health and safety standards. As argued by Tilock [35], "there is a necessity of providing cost effective technical assistance to poor clients that is tailored to their needs".

In Pakistan, disasters would be thought as an opportunity to construct a planned house. The application of design in a variety of ways, small or large, adds value to incremental housing improvement patterns and processes.

\subsubsection{Role of building material suppliers}

A 2007 study in São Paulo, reveals that one-third of the purchases of families are financed by consumer credit. The construction material stores reported that they could finance typically qualified customers a maximum of US $\$ 1500$ which covers the average cost of the building material to add one room [29]. The burden on low-income families can be reduced if materials can be drawn on credit through local commercial suppliers. Recent experience in Mexico and elsewhere has shown that there is a great potential to expand housing microfinance along with using the credit culture operated by household good retailers [36].

\subsubsection{Role of households}

Residents have the best knowledge of the characteristics of their living habits, the nature of their needs and priorities and how the incremental construction of their house will work? In his book, Housing by People, Turner [37] said "when dwellers control the major decisions and are free to make their own contribution to the design, construction or management of housing, both the process and the environment produced stimulate individual and social well being. And where dwellers are in control, their homes are typically better and cheaper than those built through government programs or large corporations."

\subsubsection{Discussion}

"Severe floods affect not only a country's infrastructure but also the education, health, water and sanitation, transportation, communications, agricultural, trade, and industrial sectors. There is a growing consensus that flood policy formulation must include multidisciplinary, multi sector, and multi stakeholder participation, initiatives, and activities to address the flood environment" Dorosh [38]. In disaster-prone countries like Pakistan, it is imperative to develop basic disaster risk-mitigation knowledge and skills not only among the policymakers and implementation groups but also among communities. Regarding post-disaster reconstruction projects in developing countries, the xUnited Nations' publication, Shelter After Disaster [39] stated "the key to success ultimately lies in the participation of the local community-the survivors-in reconstruction". Davidson, Johnson and Lizarralde [40] after studying four post-disaster reconstruction projects in El Salvador, Turkey and Colombia said that if the community is organized properly and involved in designing of the project, it has an important impact on the project with long-term advantages. 
Aims to provide rapid relief in the event of natural disasters and to establish sustainable local development projects can be gained through technical and financial support provided to communities. According to Wratten [41], "Habitat improvement schemes are more successful if different programmes, such as those dealing with income generation, housing and neighbourhood improvement, are integrated in such a way that social, economic and political and environmental problems can be taken into account". According to the Global Report on Human Settlements, 2005 "Housing Microfinance is an important potential resource for increasing the rate, scale and quality of housing supply" for low-income families. Also the improvement or extension in existing units can generate more domestic space, which can be rented out or can be used for home-based enterprise. Microfinance suits poor people of developing countries because it sprang out of their culture and was developed specifically with their needs and strengths in mind [42]. Considering the importance of financial aspects of housing, the disaster management authorities need to establish partnerships with microfinance organizations, NGOs and other development authorities to develop awareness and technical expertise in communities.

In addition to it, Pakistan needs to establish and strengthen early warning system mechanisms to ensure appropriate responses to recurring natural disasters. Such systems have the potential to contribute significantly to reduce disaster losses. Likewise, the lessons learned from the relief and rehabilitation response to the 2010 floods should be incorporated in contingency plans for future natural disasters. There should be opportunities for not only restoring infrastructure facilities but also upgrading them to enhance flood resistance [43].

\section{REFERENCES}

[1] Dilley, M., Natural Disaster Hotspots: A Global Risk Analysis, World Bank Publications: Wasington D.C, 2005. doi: http://dx.doi.org/10.1596/0-8213-5930-4

[2] Islamic Relief Report, Online: http://www.lexisnexis.com/hottopics/lnacademic/?shr=t $\& c s i=337920 \& s r=H L E A D($ Islamic+Relief+Usa)+and+date+is+August, 2011.

[3] Davidson, C.H., Johnson, C., Lizarralde, G., et al., Truths and myths about community participation in post-disaster housing projects. Habitat International, 31(1), pp. 100-115, 2007. doi: http://dx.doi.org/10.1016/j.habitatint.2006.08.003

[4] Kaleem, A. \& Ahmed, S., The quran and poverty alleviation, nonprofit and voluntary sector quarterly, 39(3), pp. 409-428, 2010.

[5] Islamic Relief Report, Online: http://www.lexisnexis.com/hottopics/lnacademic/?shr=t $\& c s i=337920 \& s r=H L E A D($ Islamic+Relief+Usa)+and+date+is+August, 2011,

[6] Radio show by Conan, N., How To Help Flood Victims In Pakistan aired on August 10, 2010.

[7] Comfort, L., Wisner, B., Cutter, S. et al., Reframing disaster policy: the global evolution of vulnerable communities. Environmental Hazards, 1(1), pp. 39-44, 1999. doi: http:// dx.doi.org/10.3763/ehaz.1999.0105

[8] Johnson, C., Impacts of prefabricated temporary housing after disasters: 1999 earthquakes in Turkey. Habitat International, 31(1), pp. 36-52, 2007. doi: http://dx.doi. org/10.1016/j.habitatint.2006.03.002

[9] Davidson, C.H., Johnson, C., Lizarralde, G. et al., Truths and myths about community participation in post-disaster housing projects. Habitat International, 31(1), pp. 100-115, 2007. doi: http://dx.doi.org/10.1016/j.habitatint.2006.08.003

[10] Dilley, M., Natural Disaster Hotspots: A Global Risk Analysis, World Bank Publications: Washington, D.C, 2005. doi: http://dx.doi.org/10.1596/0-8213-5930-4 
[11] Dorosh, P., Malik, S. \& Krausova, M., Rehabilitating Agriculture and Promoting Food Security, following the 2010 Pakistan Floods, Pakistan Development Review 49, no. 3, pp. 167-192. 2010.

[12] Dilley, M., Natural Disaster Hotspots: A Global Risk Analysis, World Bank Publications: Wasington D.C, 2005. doi: http://dx.doi.org/10.1596/0-8213-5930-4

[13] Riaz, A., Affordable Housing Shortage and Increasing Urban Decay, ADB funded assignment, 2009.

[14] Alvi, I., The Informal Sector in Urban Economy: Low Income Housing in Lahore, Oxford University Press assignment, 1997.

[15] Riaz, A., Affordable Housing Shortage and Increasing Urban Decay, ADB funded assignment, 2009.

[16] Lizarralde, G., Organisational Design, Performance and Evaluation of Post-Disaster Reconstruction Projects, 2002.

[17] Davidson, C.H., Johnson, C., Lizarralde, G., et al., Truths and myths about community participation in post-disaster housing projects. Habitat International, 31(1), pp. 100-115, 2007. doi: http://dx.doi.org/10.1016/j.habitatint.2006.08.003

[18] Description of the current National Housing Programmes per InterventionCategory,Online: http://www.dhs.gov.za/Content/Housing Programmes/Programmes.htm2.\%20Intervention \%20Category:\%20Incremental\%20Housing\%20Programmes

[19] Ferguson, B. \& Navarrete J., A financial framework for reducing slums: lessons from experience in Latin America. Environment and Urbanization, 15(2), pp. 201-216, 2003.

[20] Abrams, C., Man's Struggle for Shelter in an Urbanizing World, 1966.

[21] Smets, P., Small is beautiful, but big is often the practice: Housing microfinance in discussion. Habitat International, 30(3), pp. 595-613, 2006. doi: http://dx.doi.org/10.1016/ j.habitatint.2005.02.003

[22] Habitat, U., Financing Urban Shelter: Global Report On Human Settlements 2005, Earthscan and UN Habitat: London, 2005.

[23] Datta, K. \& Jones, G.A., Housing and Finance in Developing Countries, Psychology Press, 1999.

[24] Boonyabancha, S., Baan Mankong: Going to scale with "slum" and squatter upgrading in Thailand. Environment and Urbanization, 17(1), pp. 21, 2005.

[25] Rojas, E. \& Greene, M., Reaching the poor: lessons from the Chilean housing experience. Environment and Urbanization, 7(2), pp. 31, 1995. doi: http://dx.doi. org/10.1177/095624789500700217

[26] Muller, A. \& Mitlin D., Securing inclusion: strategies for community empowerment and state redistribution. Environment and Urbanization, 19(2), pp. 425, 2007. doi: http://dx.doi.org/10.1177/0956247807082822

[27] Durand-Lasserve, A., Fernandes, E., Payne, G., et al., Secure tenure for the urban poor. CIVIS, Cities Alliance, pp. 1-8, 2002.

[28] Ghaznavi, A.S., Akhuwat-Microfinance with a Difference, 2006.

[29] Datta, K. \& Jones, G.A., Housing and finance in developing countries, Psychology Press, 1999.

[30] Personal communication with Shams, D.K., Director and Member of Executive Committee of Akhuwat-Lahore in May 2011.

[31] Ferguson, B., Rubinstein, J., Vial, V.D., The design of direct demand subsidy programs for housing in Latin America. Review of Urban \& Regional Development Studies, 8(2), pp. 202-219, 1996. doi: http://dx.doi.org/10.1111/j.1467-940X.1996.tb00118.x 
[32] Ferguson, B., Housing microfinance: is the glass half empty or half full?, Global Urban Development Magazine, pp. 157, 2008.

[33] Appadurai, A., Deep democracy: urban governmentality and the horizon of politics. Environment and Urbanization, 13(2), pp. 23, 2001.

[34] Smets, P., Small is beautiful, but big is often the practice: Housing microfinance in discussion. Habitat International, 30(3), pp. 595-613, 2006. doi: http://dx.doi.org/10.1016/ j.habitatint.2005.02.003

[35] Daphnis, F., Ferguson, B. \& Ebrary, I., Housing Microfinance: a Guide to Practice, Kumarian Press, 2004.

[36] Habitat, U., Financing Urban Shelter: Global Report on Human Settlements 2005, Earthscan and UN Habitat: London, 2005.

[37] Turner John, F., Housing By People: Towards Autonomy in Building Environments, Pantheon Books: New York, 1977.

[38] Dorosh, P., Malik, S. \& Krausova, M., Rehabilitating Agriculture and Promoting Food Security Following the 2010 Pakistan Floods, 2010.

[39] U. N. D. R. Co-ordinator, Shelter after disaster: guidelines for assistance: United Nations, 1982.

[40] Davidson, C.H., Johnson, C., Lizarralde, G. et al., Truths and myths about community participation in post-disaster housing projects, Habitat International, 31(1), pp. 100-115, 2007. doi: http://dx.doi.org/10.1016/j.habitatint.2006.08.003

[41] Wratten, E., Conceptualizing urban poverty. Environment and Urbanization, 7(1), pp. 11, 1995. doi: http://dx.doi.org/10.1177/095624789500700118

[42] Datta, K. \& Jones, G.A., Housing and Finance in Developing Countries: Psychology Press, 1999.

[43] Johnson, C., Impacts of prefabricated temporary housing after disasters: 1999 earthquakes in Turkey. Habitat International, 31(1), pp. 36-52, 2007. doi: http://dx.doi.org/10.1016/ j.habitatint.2006.03.002 